\title{
Review: Inhibition of prolactin as a management tool in dairy husbandry
}

\author{
P. Lacasse ${ }^{1 \dagger}$, X. Zhao $^{2}$, N. Vanacker ${ }^{1,3}$ and M. Boutinaud ${ }^{4}$ \\ ${ }^{1}$ Sherbrooke Research and Development Centre, Agriculture and Agri-Food Canada, 2000 College Street, Sherbrooke, QC, Canada J1M 0C8, ${ }^{2}$ Department of Animal \\ Science, McGill University, Sainte-Anne-de-Bellevue, QC, Canada H9X 3Vg; ${ }^{3}$ Département de Biologie, Faculté des Sciences, Université de Sherbrooke, Sherbrooke, \\ QC, Canada J1K 2R1; ${ }^{4}$ INRA, UMR1348 PEGASE, F-35590 Saint-Gilles, France
}

(Received 1 August 2018; Accepted 13 November 2018)

\begin{abstract}
Accumulating evidence supports that the hormone prolactin (PRL) is galactopoietic in dairy ruminants. Accordingly, the inhibition of PRL secretion by the dopamine agonists quinagolide and cabergoline causes a sharp decline in milk production and could be useful in several critical periods. First, PRL inhibition may reduce the incidence during the periparturient period of metabolic disorders caused by the abrupt increase in energy demand for milk production. Metabolic disturbances can be lessened by reducing milk output by milking once a day or incompletely in the first few days of lactation. The injection of cows with quinagolide for the first 4 days of lactation reduced milk production during the first week of lactation without any residual effects. Blood glucose and calcium concentrations were higher and $\beta$-hydroxybutyric acid concentration was lower in the quinagolide-treated cows. Second, PRL inhibition may help sick or injured lactating cows, considering that they can fall into severe negative energy balance when they are unable to consume enough feed to support their milk production. This leads to a weakened immune system and increased susceptibility to diseases. When cows were subjected to feed restriction and were treated with quinagolide, the decrease in milk production was accelerated without any residual effects. The quinagolide-treated cows had higher glucose and lower $\beta$-hydroxybutyric acid and non-esterified fatty acid concentrations than the control cows did. Third, PRL inhibition may facilitate drying-off in high-yielding cows, because they are often dried off while still producing significant quantities of milk, which delays mammary involution and increases risk of mastitis. Therefore, strategies that reduce milk production before drying-off and accelerate mammary gland involution could be an important management tool. In this context, inhibition of PRL was utilised to accelerate mammary gland dry-off. Quinagolide decreased milk production within the first day of treatment, and both quinagolide and cabergoline induced more rapid changes in several markers of mammary gland involution after drying-off. In addition, quinagolide improved the animals' resistance to intramammary infection. These results suggest that the inhibition of PRL could be a strategy for facilitating drying-off, reducing metabolic stress during the postpartum period, and alleviating acute nutritional stress during illness without compromising the overall productivity of dairy ruminants.
\end{abstract}

Keywords: lactation, mammary gland, quinagolide, cabergoline, dairy cows

\section{Implications}

Although the role of the hormone prolactin (PRL) in dairy ruminants has been controversial for many years, this review presents recent evidence that PRL is galactopoietic (induces the formation and secretion of milk) in ruminant lactation. We also discuss how PRL modulation could be used as a management tool to improve energy balance during the postpartum period and during acute nutritional stress as well as to facilitate drying-off.

\section{Introduction}

Ninety years ago, Stricker and Grueter (1929) reported that mammary growth and lactation could be induced in rabbits

${ }^{\dagger}$ E-mail: Pierre.Lacasse@canada.ca by injecting aqueous pituitary extracts. Subsequently, Riddle et al. (1933) determined that a hormone produced by the anterior pituitary, which they named PRL, was responsible for these effects. Although several substances can act as PRLreleasing factors, the secretion of PRL appears to be regulated primarily by the inhibitory action of dopamine released by the tuberoinfundibular neurons of the hypothalamus (Freeman et al., 2000). Diverse stimuli from the environment and the internal milieu can affect the secretion of PRL. Parturition is associated with a major peak in PRL concentration, and the suppression of PRL prevents lactogenesis (Johke, 1986). Prolactin release is also induced by suckling and milking, but this response decreases as lactation progresses (Selmanoff and Selmanoff, 1983).

Prolactin is known to be mammogenic and lactogenic in both monogastric and ruminant mammals. Although the 
galactopoietic role of PRL in monogastric lactation is well recognised, only recently has that role been demonstrated in ruminant lactation. In this review, we will present recent evidence of the galactopoietic role of PRL in ruminants. For a more comprehensive review, readers are invited to consult Lacasse et al. (2016).

The galactopoietic role of PRL in lactating dairy cows was demonstrated using PRL inhibitors. The earlier studies used bromocriptine, an ergot alkaloid which acts as a dopamine agonist and inhibits PRL secretion by lactotrophs. However, bromocriptine has affinity for serotonin and adrenergic receptors (Brownell, 1998). Quinagolide is a non-ergot dopamine agonist that binds specifically to the dopamine D2 receptor of lactotrophs and has little affinity for serotonin and $\alpha$-adrenergic binding sites (Brownell, 1998). In animal models, quinagolide has a longer half-life, has fewer side effects, and is 200 times more potent than bromocriptine in terms of inhibiting rodent lactation (Brownell, 1998). Cabergoline is also a potent dopamine D2 receptor agonist. However, it also possesses significant affinity for D3 and D4 dopamine receptors and several serotonin receptors (Sharif et al., 2009).

Lacasse et al. (2011) inhibited PRL release in lactating dairy cows by injecting them with quinagolide daily for 9 weeks. At the dose used in that study $(1 \mathrm{mg} /$ day), quinagolide reduced but did not totally prevent PRL release at milking. Nevertheless, milk production declined faster in the quinagolide-treated cows than in the control cows. Milk production was correlated with the amounts (area under the curve) and peak values of milkinginduced PRL release, and the correlation coefficients were similar in the control cows and the quinagolide-treated cows (Lacasse et al., 2011). In another study, Knight et al. (1990) reported a $21 \%$ decrease in milk production in dairy goats treated with bromocriptine for 8 days. Moreover, a single injection of cabergoline caused a $28 \%$ decrease in milk yield on the day after the injection (Figure 1). In addition, Knight (1993) showed that the effect of bromocriptine on milk production in goats was attenuated when PRL was injected with bromocriptine. Similarly, Lollivier et al. (2015) reported that the effect of quinagolide on milk production in dairy cows was attenuated by twice-daily intravenous injections of PRL $(2 \mu \mathrm{g} / \mathrm{kg} \mathrm{BW})$ at milking time. These last experiments indicate that the effect on milk production of these dopamine agonists is due to the inhibition of PRL release.

A complete demonstration of the galactopoietic function of PRL in ruminants requires showing that enhancing the PRL concentration has a positive effect on lactation. In dairy cows, although Plaut et al. (1987) observed no effect of injecting a high dose of recombinant PRL ( $120 \mathrm{mg} / \mathrm{day}$ for 14 days), Wall et al. (2006) found that injections of a much smaller dose ( $1 \mu \mathrm{g} / \mathrm{kg}$ of BW) twice a day for the first 3 weeks of lactation tended to increased milk production. Recombinant PRL injections in goats increased milk yield by over $10 \%$, an increase that was comparable and additive to the increase elicited by growth hormone (Flint and Knight, 1997). In recent experiments, Lacasse and Ollier (2015) and Tong et al. (2018) injected mid-lactation cows with a dopamine antagonist, domperidone. In both experiments, domperidone induced a gradual increase in PRL concentrations and milk



Figure 1 Milk production of dairy goats at 60 days in milk injected intramuscularly with $1 \mathrm{mg}$ of cabergoline ( $\bullet$, solid line; $n=5$ ) or water (control; $\square$, dashed line; $n=5$ ). Milk production on the day of the injection was lower $(P<0.01)$ in the goats injected with cabergoline. This figure is adapted from Lacasse et al. (2016).

production. Taken together, the results of all the experiments cited so far in this review support the view that PRL is galactopoietic in dairy ruminants. Accordingly, PRL inhibition could be used as a management tool to temporarily reduce milk production in situations where such a reduction could be beneficial. In the following sections, we will review experiments in which PRL inhibition was used to improve energy balance during the postpartum period or during acute nutritional stress or to facilitate drying-off.

\section{Prolactin inhibition as a management tool for the postpartum period}

The transition from late gestation to lactation in dairy ruminants is marked by nutritional, metabolic, hormonal and immunological changes that affect the incidence of metabolic diseases (Goff and Horst, 1997). As the demand for nutrients needed for milk synthesis increases rapidly and exceeds the intake of nutrients from food, cows are in a state of negative energy balance (NEB) (Bauman and Currie, 1980). This results in lower blood glucose, calcium and phosphorus concentrations and the mobilisation of body reserves to provide additional energy, leading to elevated blood concentrations of non-esterified fatty acids (NEFA) and $\beta$-hydroxybutyric acid (BHBA) (Drackley, 1999; Busato et al., 2002; Drackley et al., 2005). When excessive, these metabolic perturbations can lead to hypocalcaemia, ketosis, displaced abomasum and hepatic lipidosis.

Periparturient dairy cows also experience a state of immunosuppression, which can increase their susceptibility to uterine and mammary infections (Kehrli et al., 1989; Sheldon, 2004). Metabolic perturbations (Goff et al., 2002) and immunosuppression (Kimura et al., 1999 and 2002; Nonnecke et al., 2003) were found to be greatly alleviated by mastectomy, indicating that the physiological demands placed on cows by the secretion of milk play a key role in periparturient immunosuppression. Ster et al. (2012) showed that peripheral blood mononuclear cell (PBMC) proliferation and interferon- $\gamma$ secretion were lower when the cells were incubated with sera harvested in the postpartum period and that those parameters were inversely correlated with serum NEFA concentration. Similarly, the myeloperoxidase activity 
of polymorphonuclear neutrophils (PMN) was negatively correlated with the concentration of NEFA in blood (Hammon et al., 2006). In vitro, a dose-effect relationship was found between NEFA concentrations and the inhibition of lymphocyte proliferation as well as the inhibition of PMN oxidative burst (Ster et al., 2012). These results suggest that the metabolic disturbances resulting from the NEB are responsible for peripartum immunosuppression.

Improving the energy balance in the immediate postpartum period is very important in order to reduce disease incidence in dairy cows. Hence, improving the nutrient supply through the transition period has been the object of extensive research. Nevertheless, the reduction of the imbalance between nutrient supply and nutrient demand can also be reduced by temporarily decreasing the latter. Some studies have used once-a-day milking (Andersen et al., 2004; Patton et al., 2006; Loiselle et al., 2009; O'Driscoll et al., 2012) or incomplete milking (Carbonneau et al., 2012; Krug et al., 2018; Morin et al., 2018) to reduce milk production and, consequently, the NEB. Those strategies were effective in reducing the amount of milk produced by the cows and had a positive effect on their metabolism and health.

Implementing incomplete milking might be too complex for many dairy farms. Therefore, Vanacker et al. (2017) tested the hypothesis that using quinagolide to slow down the rapid increase in milk production that follows calving will decrease metabolic and immunological perturbations. The first intramuscular injection of quinagolide $(2 \mathrm{mg})$ was given as soon as possible after calving, and the following seven injections were given at 12 -h intervals. The milk production of the quinagolide-treated cows was lower from days 2 to 6 $(24.3 \pm 6.4$ and $34.8 \pm 4.1 \mathrm{~kg} /$ day $)$. There was no residual effect of quinagolide on milk production after day 6 . The quinagolide injections increased blood glucose and calcium concentrations and decreased blood BHBA concentration during the first week of lactation indicating an improvement of energy balance. Blood phosphorus, urea and NEFA concentrations were not affected by the treatment. Quinagolide administration did not affect the phagocytic ability of PMNs but enhanced the proportion of those cells that underwent oxidative burst when stimulated. The proliferation of PBMCs was not improved but was correlated negatively with NEFA concentrations in the serum.

When PRL secretion at calving is reduced by the administration of quinagolide, the postpartum increase in milk production is slowed down without compromising overall dairy cow productivity. Slowing down the increase in milk production allows a reduction in metabolic stress and, in turn, a potential reduction in the incidence of diseases during the transition period.

\section{Prolactin inhibition as a management tool during acute nutritional stress}

As a result of several conditions, such as surgery, inability to stand up, milk fever and ketosis, cows are sometimes unable to eat the amount of feed required to support milk production. Consequently, high-yielding cows fall into severe NEB and must mobilise body reserves extensively to provide the additional nutrients required for milk production. As highlighted in the previous section, cows in an energy deficit experience metabolic perturbations and have a weakened immune system, which increases their susceptibility to infectious diseases. Therefore, strategies that improve energy status may limit immunosuppression in cows experiencing acute nutritional stress.

Reducing the milk production of cows under acute nutritional stress decreases their energy deficit. Large doses of glucocorticoids such as dexamethasone inhibit milk synthesis (Braun et al., 1970; van der Kolk, 1990) and are sometimes used in cows under acute nutritional stress to temporarily reduce their milk production. However, glucocorticoids are potent immunosuppressors and increase the risk of infections (Roth and Kaeberle, 1982). Therefore, Ollier et al. (2016) conducted an experiment to determine whether the inhibition of PRL could be used to reduce metabolic perturbations and immunosuppression in cows under acute nutritional stress. The cows were subjected to an acute nutritional stress created by a severe feed restriction (they were fed $\sim 56 \%$ of their previous week's DM intake) for 5 days. After 1 day of restriction, the cows were injected with either quinagolide or water twice a day for the following 4 days. A third group of cows received a single injection of dexamethasone. Feed restriction decreased milk production, however that drop was hastened in the quinagolide-treated cows and the dexamethasone-treated cows. Accordingly, the NEB was less severe in those cows than in the control cows. Feed restriction increased plasma NEFA and BHBA concentrations and decreased plasma glucose concentration, but those effects were attenuated by the PRL inhibitor. Dexamethasone injection also decreased BHB and NEFA concentrations initially but increased them subsequently. Although a negative correlation between serum NEFA concentration and PBMC proliferation was observed, the negative effect of serum harvested during the restriction period on mitogeninduced PBMC proliferation was not alleviated by quinagolide. Dexamethasone injection decreased the proportion of PMN capable of inducing oxidative burst confirming the negative effect of glucocorticoids on immunity. The quinagolide-induced reduction of milk production allows the reduction of NEB and associated metabolic stress without disturbing immune functions and compromising milk production during the rest of lactation in cows subjected to acute nutritional stress.

\section{Prolactin inhibition as a management tool for drying- off}

As their milk yield increases, drying-off has become a challenging period for dairy cows. Cows are often dried off while still producing large quantities of milk (Dingwell et al., 2001), which greatly increases the vulnerability of the mammary 
gland to new intramammary infections (Rajala-Schultz et al., 2005). The mammary gland is much more resistant to infection once active involution is completed. Therefore, strategies that reduce milk production before dry-off, accelerate mammary gland involution or both could be important management tools.

In this context, PRL inhibition could be used to reduce milk production at drying-off and accelerate the rate of mammary involution after cessation of milking. In one experiment, Ollier et al. (2013) injected late-lactation cows twice daily with quinagolide or water from 4 days before dry-off until 3 days after. The PRL inhibitor reduced milk production before dry-off by $20 \%$. The increases in somatic cells and bovine serum albumin in milk during early involution were greater in the quinagolide-treated cows, suggesting that involution was accelerated. In another experiment, Ollier et al. (2014) compared the effects of injecting quinagolide from 5 days before dry-off until 13 days after with the effects of a drastic feed restriction in the days that preceded drying-off, a method commonly used to reduce milk production. The feedrestricted cows were fed dry hay only during the last 5 days before dry-off. A control group was neither feed-restricted nor injected with quinagolide. Both treatments decreased milk production at the time of drying-off and hastened mammary gland involution. Whereas quinagolide had little effect on blood metabolites, feed restriction increased blood concentrations of BHBA and NEFA and decreased blood concentrations of glucose and most amino acids. Serum harvested on the drying-off day from the hay-fed cows reduced the proliferation and interleukin-4 production of PBMCs, indicating immunosuppression. The same two treatments were repeated on another group of cows, but they were challenged by daily teat dipping in a solution containing Streptococcus agalactiae during the first week of the dry period (Ollier et al., 2015). Although both feed restriction and quinagolide injections induced a major decrease in milk production, only the PRL-inhibition strategy reduced the incidence of new intramammary infections at drying-off (Figure 2).

Another dopamine agonist, cabergoline, was tested as a management tool to facilitate drying-off. The strategy used with this inhibitor was different from the one used with quinagolide: a single injection of cabergoline was administered just after the last milking before dry-off. Although the effect of cabergoline on milk yield could not be measured directly, udder pressure and firmness as well as milk leakage were reduced in the treated cows, indicating a reduction in milk synthesis (Bach et al., 2015; Bertulat et al., 2017). In addition, enhanced extracellular matrix remodelling in the mammary gland, the exfoliation of mammary epithelial cells into milk, and the changes observed in the composition of mammary secretions indicated that cabergoline treatment hastened mammary gland involution (Boutinaud et al., 2016 and 2017). Even though the effect of cabergoline on resistance to intramammary infection was not tested, the more rapid increase in lactoferrin concentration, a bacteriostatic protein, in mammary secretions (Boutinaud et al., 2016) may help to prevent intramammary infection.
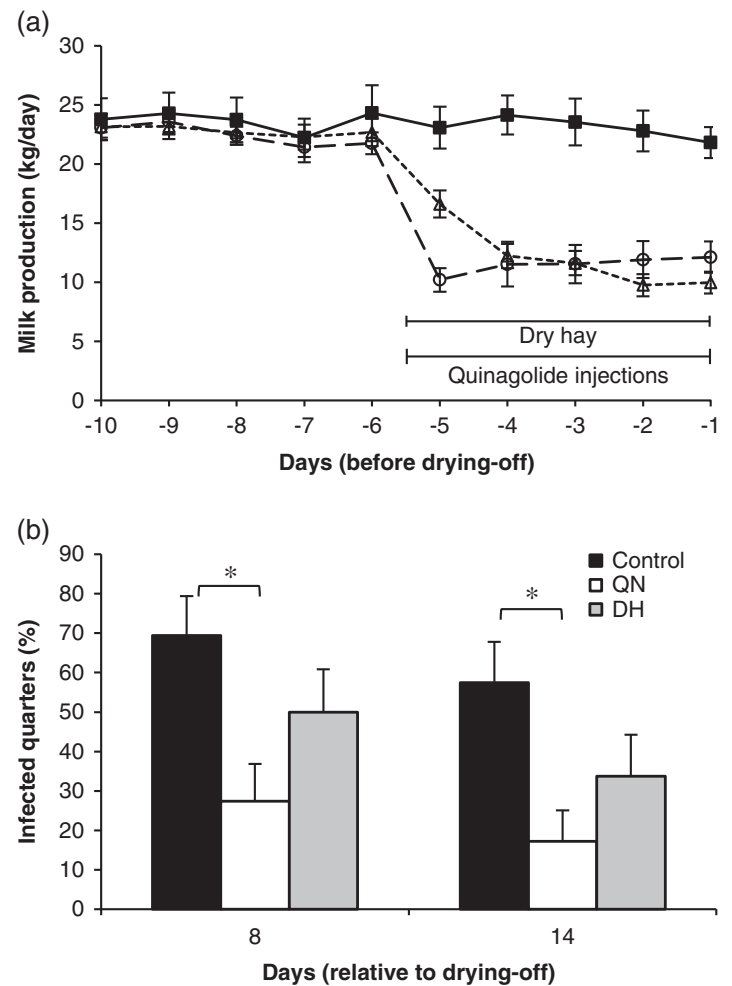

Figure 2 (a) Milk production on the days preceding drying-off and (b) infection rate in mammary secretions of cows injected twice daily with quinagolide $(4 \mathrm{mg})$ from 5 days before drying-off until 13 days after $(\mathrm{O}$, long-dashed line; $\mathrm{QN})$, cows fed dry hay only for the 5 days before drying-off $(\Delta$, short-dashed line; $\mathrm{DH})$, and control cows $(\boldsymbol{\square}$, solid line). From day 1 to 7 after the last milking, all teats of each cow were dipped daily in a solution containing Streptococcus agalactiae at $5 \times 10^{7} \mathrm{cfu} / \mathrm{ml}$. ${ }^{*} P<0.05$. This figure is adapted from Ollier et al. (2015).

In light of the research results obtained in various studies, a cabergoline-based product, Velactis, was commercialised in Europe and some Latin American countries. However, it was withdrawn from the European market after some cows were reported to suffer symptoms similar to a periparturient hypocalcaemia. The role of PRL in calcium homoeostasis is well established in fish (Flik et al., 1994), and bromocriptine was reported to decrease calcium absorption in rats (James et al., 1977). It is therefore reasonable to think that the inhibition of PRL might cause hypocalcaemia. However, an improved calcaemia was observed in periparturient cows treated with quinagolide (Vanacker et al., 2017), although PRL secretion was inhibited only for $\sim 4$ days. To determine whether PRL manipulations can affect calcium homoeostasis, we determined calcium concentrations in serum samples collected in lactating cows injected with quinagolide or water for 2 weeks and then treated with domperidone for the following 3 weeks (Tong et al., 2018). Even though PRL blood concentration was altered by 30 -fold, no significant change in serum calcium concentrations was observed (Figure 3). This finding indicates that lowering the PRL concentration is unlikely to cause hypocalcaemia.

In some situations, it appears that the responsiveness of the mammary gland to the PRL galactopoietic signal is modulated by local or systemic factors (Lacasse et al., 2016). 

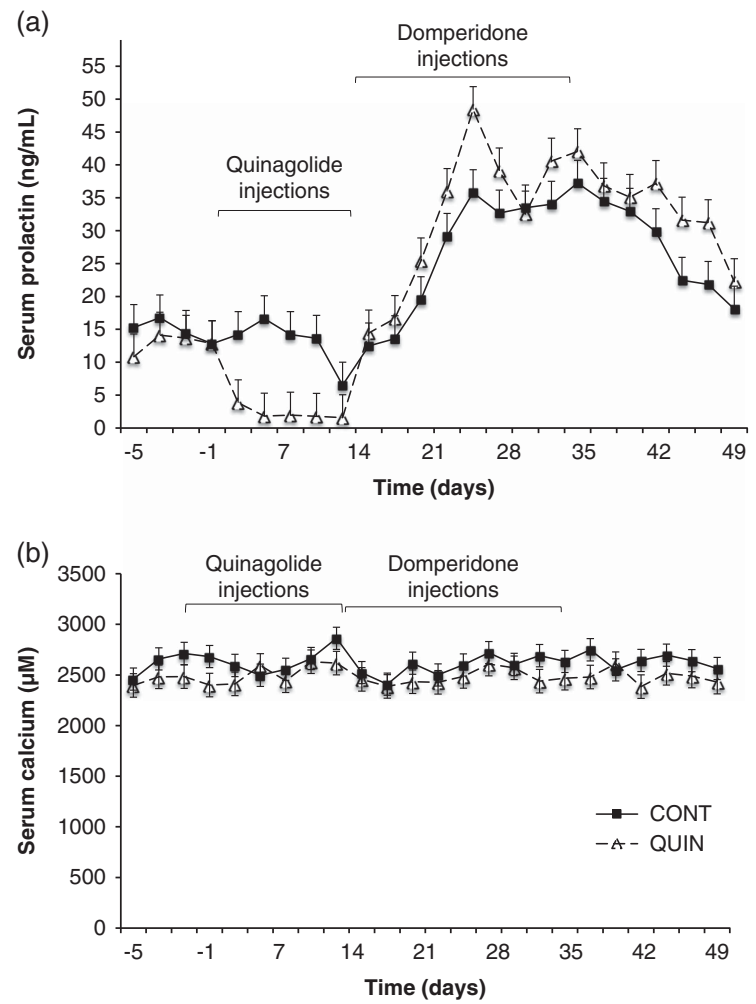

Figure 3 Serum concentrations of (a) prolactin and (b) calcium in dairy cows injected with either quinagolide $(0.5 \mathrm{mg} / \mathrm{ml} ; \Delta$, dashed line; $n=9$; QUIN) or water ( $2.0 \mathrm{ml} ;$, solid line; $n=9$; CONT) from day 1 to 14 . All cows were injected daily with domperidone $(300 \mathrm{mg})$ from day 15 to 35 . Serum prolactin was lower $(P<0.05)$ in the quinagolide-treated cows from day 5 to 14 . Serum calcium was not affected by the quinagolide or domperidone injections. Panel (a) is adapted from Tong et al. (2018).

The circulating level of PRL might also have an impact on mammary gland responsiveness to PRL. A short-day photoperiod during the dry period was found to reduce circulating PRL during that period and increase the subsequent milk production (Auchtung et al., 2005; Lacasse et al., 2014). In Lacasse et al. (2014), milk production in the first 20 weeks of lactation was enhanced by about $10 \%$ by previous exposure to a short-day photoperiod during the dry period. Accordingly, the infusion of recombinant PRL into dry cows exposed to a short-day photoperiod during the dry period reduced the subsequent milk response to the photoperiod treatment (Crawford et al., 2015). In the previously cited studies on drying-off management, PRL was inhibited during the early dry period (Ollier et al., 2013, 2014 and 2015). Even though those experiments were not designed to determine the effect of these treatments on milk production in the subsequent lactation, an increase in production was observed in the animals that had received the inhibitor (Figure 4), a result that supports the concept that PRL can influence responsiveness to its own signal. That would be a significant benefit of this strategy, and an experiment is currently ongoing to confirm this finding.

These experiments show that PRL inhibition induces a sharp decrease in the milk production of cows in late lactation, accelerates mammary gland involution, and reduces susceptibility to intramammary infections in a $S$. agalactiae

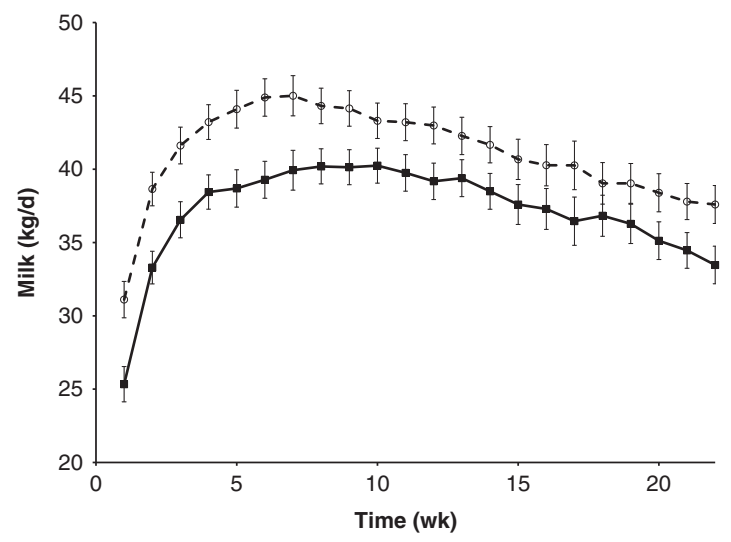

Figure 4 Milk production during the subsequent lactation of cows injected twice daily with quinagolide $(O$, dashed line) or water $(\square$, solid line) before drying-off and during the early dry period (see Ollier et al., 2013, 2014 and 2015 for more details). Milk production was greater $(P=0.02)$ in the quinagolide-treated cows. This figure is adapted from Lacasse et al. (2016).

challenge. Taken together, these results indicate that the PRL-inhibition strategy could be an alternative tool for facilitating drying-off, especially in high-yielding cows. However, a better understanding of the cause of the side effects that have been reported is needed.

\section{Conclusion}

The results of several experiments now support the hypothesis that PRL is galactopoietic in dairy cows and goats. Our results suggest that PRL inhibition could be used as a management tool to reduce metabolic stress in cows during the transition period or to assist cows under acute nutritional stress. In addition, PRL inhibitors could also be used to facilitate the drying-off of high-producing dairy cows. Nevertheless, additional research is needed to ensure the safety of such approaches for the animals.

\section{Acknowledgements}

The authors would like to thank Séverine Ollier for her outstanding contribution and the teams at the Sherbrooke Research and Development Centre (Sherbrooke, QC, Canada) and at the UMR1348 PEGASE (Rennes, France) for taking care of the cows, helping with the blood sampling and providing technical assistance. The authors are grateful to Mary Varcoe, from the Translation Bureau, Public Services and Procurement Canada, for her careful editing of this manuscript.

\section{Declaration of interest}

The authors declare no conflict of interest.

\section{Ethics statement}

Not relevant. 


\section{Software and data repository resources}

Data were not deposited in an official repository.

\section{References}

Andersen JB, Friggens NC, Larsen T, Vestergaard M and Ingvartsen KL 2004. Effect of energy density in the diet and milking frequency on plasma metabolites and hormones in early lactation dairy cows. Journal of Veterinary Medicine $A$, Physiology, Pathology, Clinical Medicine 51, 52-57.

Auchtung TL, Rius AG, Kendall PE, McFadden TB and Dahl GE 2005. Effects of photoperiod during the dry period on prolactin, prolactin receptor, and milk production of dairy cows. Journal of Dairy Science 88, 121-127.

Bach A, De-Prado A and Aris A 2015. Short communication: the effects of cabergoline administration at dry-off of lactating cows on udder engorgement, milk leakages, and lying behavior. Journal of Dairy Science 98, 7097-7101.

Bauman DE and Currie WB 1980. Partitioning of nutrients during pregnancy and lactation: a review of mechanisms involving homeostasis and homeorhesis. Journal of Dairy Science 63, 1514-1529.

Bertulat S, Isaka N, de Prado A, Lopez A, Hetreau T and Heuwieser W 2017. Effect of a single injection of cabergoline at dry off on udder characteristics in high-yielding dairy cows. Journal of Dairy Science 100, 3220-3232.

Boutinaud M, Isaka N, Gandemer E, Lamberton P, Wiart S, De Prado Taranilla Al, Sordillo LM and Lollivier V 2017. Inhibiting prolactin by cabergoline accelerates mammary gland remodeling during the early dry period in dairy cows. Journal of Dairy Science 100, 9787-9798.

Boutinaud M, Isaka N, Lollivier V, Dessauge F, Gandemer E, Lamberton P, De Prado Taranilla Al, Deflandre A and Sordillo LM 2016. Cabergoline inhibits prolactin secretion and accelerates involution in dairy cows after dry-off. Journal of Dairy Science 99, 5707-5718.

Braun RK, Bergman EN and Albert TF 1970. Effects of various synthetic glucocorticoids on milk production and blood glucose and ketone body concentrations in normal and ketotic cows. Journal of the American Veterinary Medical Association 157, 941-946.

Brownell J 1998. Quinagolide in hyperprolactinaemia. Reviews in Contemporary Pharmacotherapy 9, 1-75.

Busato A, Faissler D, Küpfer U and Blum JW 2002. Body condition scores in dairy cows: associations with metabolic and endocrine changes in healthy dairy cows. Journal of Veterinary Medicine A, Physiology, Pathology, Clinical Medicine 49, $455-460$.

Carbonneau E de Passillé AM, Rushen J, Talbot BG and Lacasse P 2012. The effect of incomplete milking or nursing on milk production, blood metabolites, and immune functions of dairy cows. Journal of Dairy Science 95 , 6503-6512.

Crawford HM, Morin DE, Wall EH, McFadden TB and Dahl GE 2015. Evidence for a role of prolactin in mediating effects of photoperiod during the dry period. Animals 5, 803-820.

Dingwell RT, Kelton DF, Leslie KE and Edge VL 2001. Deciding to dry-off: does level of production matter? In National Mastitis Council Annual Meeting Proceedings, 11-14 February 2001, Arlington, VA, USA, pp. 69-79.

Drackley JK 1999. Biology of dairy cows during the transition period: the final frontier? Journal of Dairy Science 82, 2259-2273.

Drackley JK, Dann HM, Douglas GN, Janovick Guretzky NA, Litherland NB, Underwood JP and Loor JJ 2005. Physiological and pathological adaptations in dairy cows that may increase susceptibility to periparturient diseases and disorders. Italian Journal of Animal Science 4, 323-344.

Flik G, Rentier-Delrue F and Wendelaar Bonga SE 1994. Calcitropic effects of recombinant prolactins in Oreochromis mossambicus. American Journal of Physiology 266, R1302-R1308.

Flint DJ and Knight CH 1997. Interactions of prolactin and growth hormone (GH) in the regulation of mammary gland function and epithelial cell survival. Journal of Mammary Gland Biology and Neoplasia 2, 41-48.

Freeman ME, Kanyicska B, Lerant A and Nagy G 2000. Prolactin: structure, function, and regulation of secretion. Physiological Reviews 80, 1523-1631.

Goff JP and Horst RL 1997. Physiological changes at parturition and their relationship to metabolic disorders. Journal of Dairy Science 80, 1260-1268.

Goff JP, Kimura K and Horst RL 2002. Effect of mastectomy on milk fever, energy, and vitamins $A, E$, and beta-carotene status at parturition. Journal of Dairy Science 85, 1427-1436.
Hammon DS, Evjen IM, Dhiman TR, Goff JP and Walters JL 2006. Neutrophil function and energy status in Holstein cows with uterine health disorders. Veterinary Immunology and Immunopathology 113, 21-29.

James MF, Makeen AM, Foley S, Stevens J and Robinson CJ 1977. Effects of prolactin and bromocriptine upon calcium and phosphorus absorption in lactating and non-lactating rats. Journal of Endocrinology 75, 53P-54P.

Johke T 1986. Prolactin secretion and lactogenesis in dairy cows and goats. Vlaams Diergeneeskundig Tijdschrift 55, 251-257.

Kehrli ME Jr, Nonnecke BJ and Roth JA 1989. Alterations in bovine neutrophil function during the periparturient period. American Journal of Veterinary Research 50, 207-214.

Kimura K, Goff JP and Kehrli ME Jr 1999. Effects of the presence of the mammary gland on expression of neutrophil adhesion molecules and myeloperoxidase activity in periparturient dairy cows. Journal of Dairy Science 82, 2385-2392.

Kimura K, Goff JP, Kehrli ME Jr, Harp JA and Nonnecke BJ 2002. Effects of mastectomy on composition of peripheral blood mononuclear cell populations in periparturient dairy cows. Journal of Dairy Science 85, 1437-1444.

Knight CH 1993. Prolactin revisited. Hannah Research Institute Yearbook (ed. E Taylor), pp. 72-80. Thomson, Glasgow, UK.

Knight $\mathrm{CH}$, Foran D and Wilde $\mathrm{CJ}$ 1990. Interaction between autocrine and endocrine control of milk yield: thrice-daily milking and bromocriptinetreated goats. Journal of Reproduction and Fertility Abstract Series 5, 30.

Krug C, Morin PA, Lacasse P, Santschi DE, Roy JP, Dubuc J and Dufour S 2018. A randomized controlled trial on the effect of incomplete milking during the first 5 days in milk on culling hazard and on milk production and composition of dairy cows. Journal of Dairy Science 101, 4367-4377.

Lacasse P, Lollivier V, Bruckmaier RM, Boisclair YR, Wagner GF and Boutinaud M 2011. Effect of the prolactin-release inhibitor quinagolide on lactating dairy cows. Journal of Dairy Science 94, 1302-1309.

Lacasse P and Ollier S 2015. The dopamine antagonist domperidone increases prolactin concentration and enhances milk production in dairy cows. Journal of Dairy Science 98, 7856-7864.

Lacasse $P$, Ollier S, Lollivier V and Boutinaud M 2016. New insights into the importance of prolactin in dairy ruminants. Journal of Dairy Science 99, 864-874. Lacasse $P$, Vinet CM and Petitclerc D 2014. Effect of prepartum photoperiod and melatonin feeding on milk production and prolactin concentration in dairy heifers and cows. Journal of Dairy Science 97, 3589-3598.

Loiselle MC, Ster C, Talbot BG, Zhao X, Wagner GF, Boisclair YR and Lacasse P 2009. Impact of postpartum milking frequency on the immune system and the blood metabolite concentration of dairy cows. Journal of Dairy Science 92, 1900-1912.

Lollivier V, Lacasse P, Angulo Arizala J, Lamberton P, Wiart S, Portanguen J, Bruckmaier RM and Boutinaud M 2015. In vivo inhibition followed by exogenous supplementation demonstrates galactopoietic effects of prolactin on mammary tissue and milk production in dairy cows. Journal of Dairy Science 98, 8775-8787.

Morin PA, Krug C, Chorfi Y, Dubuc J, Lacasse P, Roy JP, Santschi DE and Dufour S 2018. A randomized controlled trial on the effect of incomplete milking during early lactation on ketonemia and body condition loss in Holstein dairy cows. Journal of Dairy Science 101, 4513-4526.

Nonnecke BJ, Kimura K, Goff JP and Kehrli ME Jr 2003. Effects of the mammary gland on functional capacities of blood mononuclear leukocyte populations from periparturient cows. Journal of Dairy Science 86, 2359-2368.

O'Driscoll K, Olmos G, Llamas Moya S, Mee JF, Earley B, Gleeson D, O'Brien B and Boyle $L$ 2012. A reduction in milking frequency and feed allowance improves dairy cow immune status. Journal of Dairy Science 95, 1177-1187.

Ollier S, Beaudoin F, Vanacker N and Lacasse P 2016. Effect of reducing milk production using a prolactin-release inhibitor or a glucocorticoid on metabolism and immune functions in cows subjected to acute nutritional stress. Journal of Dairy Science 99, 9949-9961.

Ollier S, Zhao X and Lacasse P 2013. Effect of prolactin-release inhibition on milk production and mammary gland involution at drying-off in cows. Journal of Dairy Science 96, 335-343.

Ollier S, Zhao X and Lacasse P 2014. Effects of feed restriction and prolactinrelease inhibition at drying off on metabolism and mammary gland involution in cows. Journal of Dairy Science 97, 4942-4954.

Ollier S, Zhao $X$ and Lacasse $P$ 2015. Effects of feed restriction and prolactinrelease inhibition at drying-off on susceptibility to new intramammary infection in cows. Journal of Dairy Science 98, 221-228. 
Patton J, Kenny DA, Mee JF, O'Mara FP, Wathes DC, Cook M and Murphy JJ 2006. Effect of milking frequency and diet on milk production, energy balance, and reproduction in dairy cows. Journal of Dairy Science 89, 1478-1487.

Plaut K, Bauman DE, Agergaard N and Akers RM 1987. Effect of exogenous prolactin administration on lactational performance of dairy cows. Domestic Animal Endocrinology 4, 279-290.

Rajala-Schultz PJ, Hogan JS and Smith KL 2005. Short communication: association between milk yield at dry-off and probability of intramammary infections at calving. Journal of Dairy Science 88, 577-579.

Riddle 0, Bates RW and Dykshorn SW 1933. The preparation, identification and assay of prolactin - a hormone of the anterior pituitary. American Journal of Physiology 105, 191-216.

Roth JA and Kaeberle ML 1982. Effect of glucocorticoids on the bovine immune system. Journal of the American Veterinary Medical Association 180 894-901.

Selmanoff M and Selmanoff C 1983. Role of pup age, estradiol-17 beta and pituitary responsiveness in the differences in the suckling-induced prolactin response during early and late lactation. Biology of Reproduction 29 , 400-411.

Sharif NA, McLaughlin MA, Kelly CR, Katoli P, Drace C, Husain S, Crosson C, Toris C, Zhan G-L and Camras C 2009. Cabergoline: pharmacology, ocular hypotensive studies in multiple species, and aqueous humor dynamic modulation in the cynomolgus monkey eyes. Experimental Eye Research 88, 386-397. Sheldon IM 2004. The postpartum uterus. Veterinary Clinics of North America: Food Animal Practice 20, 569-591.

Ster C, Loiselle MC and Lacasse P 2012. Effect of postcalving serum nonesterified fatty acids concentration on the functionality of bovine immune cells. Journal of Dairy Science 95, 708-717.

Stricker P and Grueter F 1929. Fonctions du lobe antérieur de I'hypophyse: Influence des extraits du lobe antérieur sur l'appareil génital de la lapine et sur la montée laiteuse. La Presse Médicale 37, 1268-1271.

Tong JJ, Thompson IM, Zhao X and Lacasse P 2018. Effect of the concentration of circulating prolactin on dairy cows' responsiveness to domperidone injection. Journal of Dairy Science 101, 2579-2587.

van der Kolk JH 1990. The bovine pituitary-adrenocortical axis and milk yield. The Veterinary Quarterly 12, 114-120.

Vanacker N, Ollier S, Beaudoin F, Blouin R and Lacasse P 2017. Effect of inhibiting the lactogenic signal at calving on milk production and metabolic and immune perturbations in dairy cows. Journal of Dairy Science 100, 5782-5791.

Wall EH, Crawford HM, Ellis SE, Dahl GE and McFadden TB 2006. Mammary response to exogenous prolactin or frequent milking during early lactation in dairy cows. Journal of Dairy Science 89, 4640-4648. 